\title{
Pater Oton Škola in njegov rokopisni slovar Pronouncing Dictionary - English and German (1839)
}

\author{
Simona ŠTAVBaR \\ SI-2000 Maribor,simonastavbar@gmail.com
}

\author{
SCN XI/1 [2018], 45-59
}

V prispevku je obravnavan rokopisni slovar Pronouncing Dictionary - English and German ${ }^{1}$ slovenskega frančiškana, misijonarja, leksikografa in slikarja p. Otona Škole. Slovar iz leta 1839 je po mojem védenju edini ohranjeni primer izgovarjalnega slovarja, ki ga je pripravil slovenski misijonar, najverjetneje za lastno rabo, tj. da se nauči tujega jezika (angleščine) za potrebe misijonarjenja. Njegov obstoj v slovenski strokovni literaturi ni natančneje obravnavan. V prispevku je na kratko predstavljeno življenje in delo frančiškana in misijonarja p. Otona Škole. Sledi metaleksikografski opis rokopisnega slovarja, nato pa so opisane nekatere njegove mikrostrukturne značilnosti.

Ključne besede: rokopisni slovar, izgovarjalni slovar, misijonarsko slovaropisje, metaleksikografski opis

The article discusses the manuscript dictionary Pronouncing Dictionary - English and German compiled by the Slovenian Franciscan missionary, lexicographer and painter, Fr. Otto Skolla. The dictionary from 1839 is to my knowledge the only preserved example of a pronouncing dictionary compiled by the Slovenian missionary, probably for his own use, i. e. to learn a foreign language (English) for the purpose of his missionary work. The dictionary has thus far not been discussed in more detail in Slovenian scholarly literature. The article offers a short presentation of the life and work of the Franciscan missionary Fr. Otto Skolla followed by the metalexicographic description and the description of certain microstructural characteristics of this dictionary.

Key words: manuscript dictionary, pronouncing dictionary, missionary lexicography, metalexicographic description

\footnotetext{
${ }^{1}$ V nadaljevanju PD-EG.
} 


\section{Jezikovni priročniki kot pripomočki misijonarjem pri njihovem misijonskem delu}

Glosarje, slovarje in druge leksikografske priročnike ter tudi slovnice so misijonarji v 19. stol. in prej na območju Severne Amerike in tudi drugod pripravljali za lastno rabo, ker so se želeli naučiti katerega od prevladujočih sporazumevalnih jezikov (angleško, francosko, nemško) oz. jezika katerega od indigenih ljudstev za potrebe misijonarjenja ali za rabo širše misijonarske skupnosti kot pripomoček pri usvajanju katerega od jezikov indigenih ljudstev. ${ }^{2}$ Navezovanje in vzdrževanje stikov s pripadniki drugih ljudstev in kultur je namreč potekalo s pomočjo tolmačev in/ali z usvajanjem določenega ciljnega jezika, pri čemer je bila ključnega pomena priprava in raba slovarjev, glosarjev in drugih leksikografskih priročnikov ter slovnic kot pripomočkov pri odpravljanju jezikovnih preprek pri sporazumevanju in pri usvajanju ciljnih jezikov. Znanje določenega ciljnega jezika je namreč omogočalo misijonarjenje in v veliki meri tudi vplivalo na uspešnost misijonarjenja med evropskimi priseljenci in indigenimi ljudstvi Severne Amerike. ${ }^{3}$

Misijonarji običajno niso imeli kakšne posebne jezikoslovne izobrazbe, zato tudi večina ohranjenih leksikografskih priročnikov z redkimi izjemami nima posebne jezikoslovne vrednosti. ${ }^{4} \mathrm{~V}$ prispevku predstavljeni izgovarjalni slovar p. Otona Škole je po mojem védenju edini ohranjeni primer izgovarjalnega slovarja, ki ga je pripravil slovenski misijonar, najverjetneje za lastno rabo, tj. da se nauči tujega jezika (angleščine) za potrebe misijonarjenja. Njegov obstoj v slovenski strokovni literaturi ni natančneje obravnavan. Tudi življenje in delovanje frančiškana in misijonarja p. Otona Škole danes širši slovenski javnosti nista znana. Zato v nadaljevanju najprej navajam nekaj pomembnejših biografskih podatkov o tem misijonarju.

\footnotetext{
${ }^{2}$ Prim. Baragov slovar A Dictionary of the Otchipwe Language (1853), ki je bil namenjen misijonarjem, delujočim med Indijanci iz ljudstva Očipve.

${ }^{3}$ Seelye v disertaciji »Come into the habits of civilized life«: nineteenth century Catholic and Protestant missionaries in Upper Michigan (2010: 108) navaja metodističnega duhovnika Johna Pitzla, ki katoliškim misijonarjem priznava, da so uspešni, ker se učijo jezika indigenih ljudstev in pridigajo $\mathrm{v}$ njem, $\mathrm{s}$ tem pa pridobijo zaupanje, ki ga ne more pridobiti nekdo, ki nima daljšega stika z domačini in je odvisen od tolmača. Seelye še navaja, da je Baraga takoj razumel pomen učenja očipvejščine in drugih jezikov indigenih ljudstev. Pitzel in drugi protestanti pa se niso učili jezikov indigenih ljudstev in so bili v pretežni meri odvisni od tolmačev (prav tam: 128).

${ }^{4}$ Vendar poznamo izjeme. K tem lahko štejemo navedeni Baragov slovar (1853), ki je doživel več izdaj in ponatisov in ga navaja oz. obravnava strokovna literatura $\mathrm{z}$ jezikoslovnega področja.
} 


\section{2 Življenje in delovanje p. Otona Škole}

Življenje in delo frančiškanskega duhovnika in misijonarja p. Otona Škole je predstavljeno v publikaciji Ave Maria Koledar $(1916)^{5}$ in v Slovenskem biografskem leksikonu 3 (1960-1971) ${ }^{6}$ ter na kratko opisano v Splošnem religijskem leksikonu (2007). O njem sta pisala frančiškan in pisatelj p. Florentin Hrovat v Cvetju z vertov sv. Frančiška (1889-1890) ${ }^{7}$ ter slovenski duhovnik, misijonar in zgodovinar Anton Ivan Režek ${ }^{8} \mathrm{v}$ delu History of the Diocese of Sault Ste. Marie and Marquette (1906). V nadaljevanju navajam nekaj pomembnejših biografskih podatkov, delno povzetih iz navedenih del.

Pater Oton Škola9 se je rodil 4. novembra 1805 v meščanski družini v Novem mestu. Pri krstu je prejel ime Karel Nikolaj. Osnovno šolo in gimnazijo je obiskoval v Novem mestu in leta 1827 vstopil v frančiškanski noviciat. V duhovnika je bil posvečen 25 . septembra 1831. Naslednjih deset let je deloval $v$ frančiškanskih samostanih, in sicer v Nazarjah in nato na Trsatu, kjer se je od leta 1836 dalje pripravljal na misijonsko delo med severnoameriškimi Indijanci. 24. septembra 1841 je $\mathrm{z}$ dovoljenjem redovnih predstojnikov zapustil domovino in z jadrnico Falmouth odpotoval v New York (ZDA, v zvezni državi New York), kamor je pripotoval 25. decembra 1841.

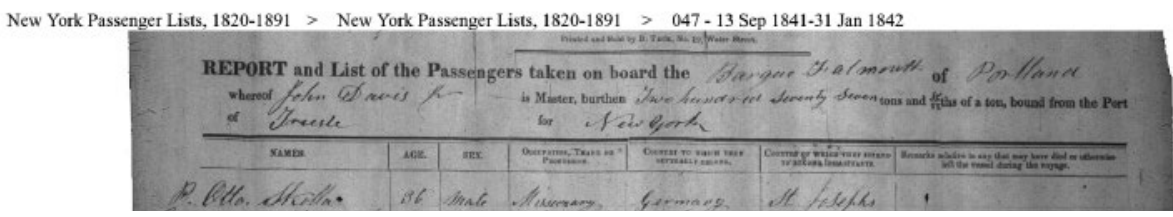

Slika 1: Seznam ladijskih potnikov na jadrnici Falmouth za čas od 13. sept. 1841 do 31. jan. 1842 z navedbo misijonarja p. Otta Skolle kot potnika ${ }^{10}$

Po prihodu v Združene države Amerike je bil kaplan v nemški narodni cerkvi sv. Nikolaja [St. Nicholas Church] v New Yorku. Maja 1842 je odpotoval iz

${ }^{5}$ To besedilo je bilo vsebinsko nespremenjeno natisnjeno tudi v listu Ave Maria (1987).

${ }^{6}$ Prim. tudi http://www.slovenska-biografija.si/oseba/sbi575994/ (dostop 25. 4. 2017).

${ }^{7}$ P. Florentin Hrovat: P. Oton Skola, apost. misijonar Indijanov v severni Ameriki (s 3 podobicami). Cvetje z vertov sv. Frančiška, IX, 1889-1890.

${ }^{8} \mathrm{~V}$ delu History of the Diocese of Sault Ste. Marie (1906) se je podpisal kot Antoine Ivan Rezek.

${ }^{9}$ V slovarju $P D-E G$ (1839) se je podpisal Otto Skolla (prim. notranjo stran platnice slovarja). V Slovenskem biografskem leksikonu 3 (1960-1971: 333) so variante njegovega priimka še Schkola, Skola, Skala in Škola, v Nekrologiju Hrvatske franjevačke provincije Ćirila i Metoda (2014: 257) pa kot Oto Karlo Škola. Režek (1906) navaja varianto Otton Skolla. Različne variante misijonarjevega imena kažejo na to, da so osebna lastna imena v preteklosti prevajali, in sicer običajno takrat, ko so se rabila v obmejnih območjih ali pri prestopu v drugo jezikovno kulturo (prim. Grah 2002: 23).

${ }^{10}$ Dosegljivo na: https://familysearch.org/ark:/61903/1:1:QVPF-3NST (dostop 24. 8. 2017). 
New Yorka v Detroit (Michigan), kjer ga je sprejel škof Lefevere. Tu je opravljal duhovniško službo med nemško in francosko govorečimi katoličani. ${ }^{11} \mathrm{~V}$ času delovanja v Detroitu je p. Oton Škola poleg rednega duhovniškega dela pomagal še na bližnjih nemških in francoskih misijonih. 1843 je bil poslan na otok Michilimackinac (danes Mackinac Island), kjer je opravljal duhovniško službo med francosko govorečimi Kanadčani in rasno mešanimi prebivalci. Od leta 1845 do 1853 je deloval kot Baragov duhovni pomočnik med indijanskim ljudstvom Očipve (Ojibwa, tudi Chippewa) in bil zadolžen za duhovno oskrbo misijona v La Pointu s pripadajočimi misijonskimi postajami (Fond du Lac in Grand Portage v Minnesoti). Oktobra 1853 je zapustil La Pointe in pričel delovati med indijanskim ljudstvom Menomini (Menominee) ob reki Oconto (Wisconsin). Ko so se morali Indijanci leta 1854 po odločitvi vlade ZDA umakniti s tega območja, jim je sledil v Kesheno (Wisconsin), kjer je zgradil manjšo cerkev sv. Mihaela. Zaradi finančnih težav, slabega zdravja in obtožb črne magije s strani peščice Indijancev je oktobra leta 1857 zapustil Kesheno in odpotoval v Allegany (New York), kjer je več mesecev bival v tamkajšnji frančiškanski skupnosti in pomagal v bližnjih misijonih. Jeseni leta 1858 se je vrnil v Evropo. ${ }^{12}$ Štiri leta je nato deloval kot nemški in slovanski spovednik pri frančiškanih v Assisiju (Italija). ${ }^{13}$ Ker se njegovo zdravstveno stanje ni izboljšalo, se je vrnil v domovino (Kostanjevica, Nazarje), nato pa je bil premeščen na Trsat. Umrl je 25. aprila $1879^{14}$ na Trsatu, kjer je tudi pokopan. ${ }^{15}$

P. Oton Škola se je poleg svoje duhovniške službe ukvarjal tudi z risarstvom in slikarstvom (slikal je akvarele). ${ }^{16}$ Svoje risarske talente je uporabljal tudi pri

${ }^{11}$ Tu je nasledil duhovnika Martina Kundiga, ki se je zaradi bolezni odselil v Milwaukee in nadaljeval gradnjo cerkve Matere Božje [Old St. Mary's Church], ki so jo pričeli graditi leta 1841, dogradili pa so jo 1843 (prim. http://detroit1701.org/St.\%20Mary\%27s.html\#. WaBEUCiGNPY (dostop 25. 8. 2017).

${ }^{12}$ Po podatkih v Nekrologiju Hrvatske franjevačke provincije Ćirila i Metoda (2014: 257) je med Indijanci v Severni Ameriki misijonaril sedemnajst let.

${ }^{13}$ Zgodnja Danica: katoliški cerkveni list, 23. 12. 1858.

${ }^{14}$ V Slovenskem biografskem leksikonu 3 (1960-1971: 333) je kot datum smrti naveden 24. april 1879. Enako je navedeno v spletni Slovenski biografiji (prim. http://www.slovenska-biografija.si/oseba/sbi575994/ (dostop 25. 4. 2017). Nekrologij Hrvatske franjevačke provincije Ćirila i Metoda (2014: 257) kot datum smrti navaja 25. april 1879. Ta datum je verjetnejši, ker je umrl na Trsatu.

${ }^{15} \mathrm{~V}$ ponatisnjenem besedilu v listu Ave Maria je navedeno, da »[M]al križ z navadnim napisom še kaže mesto, kjer počiva ta veliki misijonar« (1987: 326). Žal ni več znano, kje točno je njegov grob, saj je staro trsatsko pokopališče opuščeno (danes je tam nasad sliv, ostanek pokopališkega zidu in uničeni grobnici), v novo frančiškansko grobnico na trsatskem mestnem pokopališču pa pokopavajo od 1909 dalje; prekopa ni bilo.

${ }^{16}$ Režek (1906: 361, 363, 366) navaja, da je Skolla narisal oz. naslikal več misijonskih cerkva in misijonskih postaj, na katerih je deloval. V listu Ave Maria (1987: 211) je navedeno, da je za misijonarja Franca Pirca naslikal Marijino podobo, ki jo je ta vstavil v oltar cerkve v Crow Wingu. 
misijonskem delovanju, in sicer za spodbujanje treznosti med Indijanci (v ta namen je ustanovil »Sobriety Society« [Društvo treznosti]). ${ }^{17}$



Slika 2: P. Oton Škola, misijonar in slikar ter avtor rokopisnega angleško-nemškega izgovarjalnega slovarja PD-EG (1839) ${ }^{18}$

Morda je bil v njegovi posesti do vrnitve $\mathrm{v}$ Evropo tudi rokopis molitve očenaš z priprošnjo k Mariji The Lord's prayer with an invocation to the Virgin v mikmaškem jeziku [St. Bonaventure University Manuscript 65], ${ }^{19}$ saj so opombe, ki sledijo molitvi, napisane z njegovo pisavo. Rokopis hranijo na isti ustanovi kot slovar. Poleg navedenega je p. Oton Škola avtor v nadaljevanju predstavljenega rokopisnega slovarja.

\section{Rokopisni slovar p. Otona Škole}

Viri omenjajo p. Otona Školo kot avtorja slovarja, razlikujejo pa se v navedbi, za kakšen slovar gre. Slovenski biografski leksikon 3 (1960-1971: 334) navaja, da je p. Oton Škola sestavil izviren indijanski slovar in da rokopis hranijo v frančiškanski knjižnici v Alleganyju. ${ }^{20}$ Vendar v knjižnici St. Bonaventure University, tj. na privatni frančiškanski visokošolski ustanovi v Alleganyju, obstoja oz. hrambe rokopisa indijanskega slovarja, kot ga navaja Slovenski biografski leksikon 3 (1960-1971), ne potrjujejo. ${ }^{21}$ Enako velja za navedbo v Splošnem

${ }^{17}$ Tudi njegov rodni brat Franc Ksaver Skola je bil amaterski slikar.

${ }^{18}$ Slika je iz dela History of the Diocese of Sault Ste. Marie (Režek 1906).

${ }^{19}$ Dostop do rokopisa je možen prek povezave: http://archives.sbu.edu/MS_Website/MuseWebsite2/sbu-post-1600-ms-65.html (dostop 3. 10. 2017).

${ }^{20}$ Prim. tudi: http://www.slovenska-biografija.si/oseba/sbi575994/ (dostop 25. 4. 2017).

${ }^{21}$ Paul Spaeth (osebna komunikacija, 13. 10. 2016), ki mi je posredoval digitaliziran Školov slovar, navaja zgolj omenjeni izgovarjalni slovar, ne pa tudi obstoja oz. hrambe rokopisnega indijanskega slovarja z avtorstvom p. Otona Škole. 
religijskem leksikonu, kjer piše, da je Oton Škola sestavil očipvejsko-francoski slovar (v rokopisu) (2007: 1209). V Ave Maria Koledarju pa je navedeno, da je p. Oton Škola »[...] za 1. 1839 sestavil zanimiv angleški slovar, ki ga v rokopisu hrani semenišče St. Bonaventure, N. Y.« (Zaplotnik maj 1987: 129; prim. Zaplotnik 1916: 100). V tem viru so navedeni datum nastanka in kraj hrambe slovarja, navedba angleški slovar pa pove, da gre za enojezični slovar, kar pa se ne sklada z rokopisom, ki ga hranijo na omenjeni univerzi. V knjižnici univerze St. Bonaventure University v Alleganyju (New York) namreč hranijo rokopis angleško-nemškega izgovarjalnega slovarja $P D-E G$ (1839), katerega avtor je p. Oton Škola. St. Bonaventure University Manuscript 66 je del posebne zbirke redkih knjig in rokopisov [St. Bonaventure University Rare Books and Manuscripts - The Holy Name Library for the Franciscan Institute]. ${ }^{22}$ Slovar je v skenirani obliki od leta 2016 dosegljiv tudi na spletu.

Kot je bilo navedeno, se je p. Oton Škola od leta 1836 pa do leta 1841 , ko je zapustil domovino in odpotoval v New York, pripravljal na misijonsko delo med severnoameriškimi Indijanci. V ta čas spada tudi nastanek rokopisa izgovarjalnega slovarja, ki je datiran z letnico 1839 in naveden na notranji strani platnice pod imenom avtorja Otona Škole. ${ }^{23}$ Slovar je tako nastal še pred njegovim odhodom v misijone. ${ }^{24}$ Ta rokopisni leksikografski priročnik je bil najverjetneje pripravljen in je avtorju služil kot učno gradivo pri usvajanju angleščine (prim. Zaplotnik 1916: 72), ki jo je pozneje potreboval pri svojem misijonskem delu na območju Severne Amerike. Konkreten primer rabe angleščine navaja Režek (1906: 362), ki opisuje, da je p. Oton Škola med svojim duhovniškim delovanjem na otoku Michilimackinac (danes Mackinac Island) tamkaj nameščenim angleškim vojakom katoliške veroizpovedi pridigal $\mathrm{v}$ angleščini, ki pa je pater takrat $\mathrm{v}$ veliki meri še ni bil vešč. Tudi Baraga je svoj slovar prvič napisal s francoščino na neavtohtoni strani, a je dovolj zgodaj ugotovil, da jo bo primerneje zamenjati s tedaj že prodornejšo angleščino. Ameriška vlada je namreč vztrajala pri poučevanju angleščine in tudi Indijanci so želeli učitelje z znanjem angleščine (Walling 1990: 24). Sicer se je bilo možno sporazumevati tudi v francoščini, nemščini in očipvejščini in so morali misijonarji znati več kot le enega od naštetih jezikov (prim. Seelye 2010: 54). Iz zgoraj navedenih biografskih podatkov lahko tudi ugotovimo, da je imel p. Oton Škola svoj rokopisni slovar $\mathrm{v}$ posesti najverjetneje vse do jeseni leta 1858 , ko je prenehal z misijonskim delom in se je vrnil v Evropo. Pred odhodom tja je več mesecev bival pri tamkajšnjih frančiškanih v Alleganyju (New York), kjer so ti leta 1858

${ }^{22}$ Dostop do navedene ustanove je možen prek povezave: http://archives.sbu.edu/MS_Website/MuseWebsite2/post-1600.html (dostop 15. 9. 2017).

${ }^{23} \mathrm{~V}$ slovarju se je podpisal kot Otto Skolla. To obliko njegovega imena in priimka zasledimo od njegovega odhoda v ZDA (prim. sliko 1). Podobno ugotavlja Jaklič, ko piše, da je Škola svoje ime spremenil v Skolla v Ameriki (1931: 150).

${ }^{24}$ Francosko je znal, saj je odraščal v času Ilirskih provinc (1809-1813), nemško prav tako (prim. njegova pisma Leopoldinini družbi na Dunaju). 
ustanovili univerzo St. Bonaventure University in kjer danes hranijo njegov rokopisni slovar.

\section{Metaleksikografski opis rokopisnega slovarja p. Otona Škole ${ }^{25}$}

Angleško-nemški izgovarjalni slovar $P D-E G$ (1839) uvrščamo med slovarje, ki uporabniku ponujajo določeno vrsto podatkov, da lahko ta iz njih pridobi določene informacije $-\mathrm{v}$ tem primeru podatke o izgovoru angleških leksemov, kar je temeljni namen slovarja, podan že v naslovu. ${ }^{26}$ Rokopisni slovar p. Otona Škole je enosmerni dvojezični vir, ki omogoča slovarskemu uporabniku pasivno rabo oz. dekodiranje, tj. razumevanje govorjene in pisane angleščine 19. stol. in ni namenjen za enkodiranje. Osnovna naloga slovarja je pomagati uporabniku pri izgovarjavi in tudi pri razumevanju angleških besed. Iz te predpostavke izhajajo praktično vsa vodila o zgradbi in značilnostih slovarja, tako na ravni makrostrukture kot na ravni mikrostrukture.

Slovar ima 110 strani, od tega ima tri strani in pol dodatka [Appendix]. Rokopis je vezan in ima platnice. Na notranji strani platnice sta navedena avtor p. Otto Skolla in letnica nastanka slovarja. Najbrž je nekdo pozneje dodal zaznamek. ${ }^{27}$ Naslednja stran je naslovnica, ki vsebuje naslov slovarja, letnico nastanka ter žig z navedbo St. Bonaventure College (prim. sliko 3). Naslovnica je edino slovarsko obbesedilo. ${ }^{28}$ Pojasnila o nastanku slovarja, njegovi sestavi in rabi ni. Slovarsko osnovo tvorijo vsi v slovarju uporabljeni viri (prim. Wiegand 2000: 514). Katere vire je Škola pri pripravi slovarja uporabil, ne vemo, ker tega ne navaja. O virih tudi ne moremo sklepati posredno, ker npr. tudi podatkov o besedilni rabi v slovarskih sestavkih ni. Zato ne poznamo kriterijev za izbor iztočnic, ki so vključene v slovar. Naslovnici sledi glavni seznam slovarskih iztočnic na 106 straneh in tri strani in pol dodatka, kar pomeni, da ima slovar dva seznama iztočnic. Ta dodatek namreč prav tako vsebuje seznam iztočnic in neposredno sledi glavnemu seznamu iztočnic. Glavni seznam vsebuje 2092 iztočnic, tj. osnovnih iztočnic, ker kazalčnih iztočnic s pripadajočimi slovarskimi sestavki ni, seznam dodatka pa 70 iztočnic. Tako glavni seznam kot tudi

${ }^{25}$ Ta članek ne obravnava ustreznosti v slovar vključenih podatkov oz. ustreznega zapisa leksemov. Nastanek slovarja sega tudi v čas, ko se nemški standardni jezik še ni ustalil (prim. Zgustove ugotovitve o slovarju bratov Grimm Deutsches Wörterbuch (2006: 45).

${ }^{26}$ Te vrste slovarjev, ki uporabniku ponujajo določeno vrsto podatkov (nem. informationsspezifische Wörterbücher, angl. dictionaries of certain information types), so npr. etimološki slovarji in pravopisni slovarji (prim. Engelberg, Lemnitzer 2009: 45; Svensén 2009: 35).

${ }^{27} S B U$ so najbrž inicialke univerze, WS 66 pa najbrž pomeni, da gre za rokopis 66, kar je že bilo omenjeno. Pomen številke 466 na naslednji strani ni nikjer pojasnjen (gl. sliko $3)$.

${ }^{28}$ Osselton (1990: 1944) ugotavlja, da so bili slovarski uvodi v starejših slovarjih v svoji funkciji nerazviti. V tem primeru uvoda ni. 
dodatek ne vsebujeta podiztočnic. Skupno število iztočnic je torej 2162, kar ta slovar uvršča med slovarje majhnega obsega.

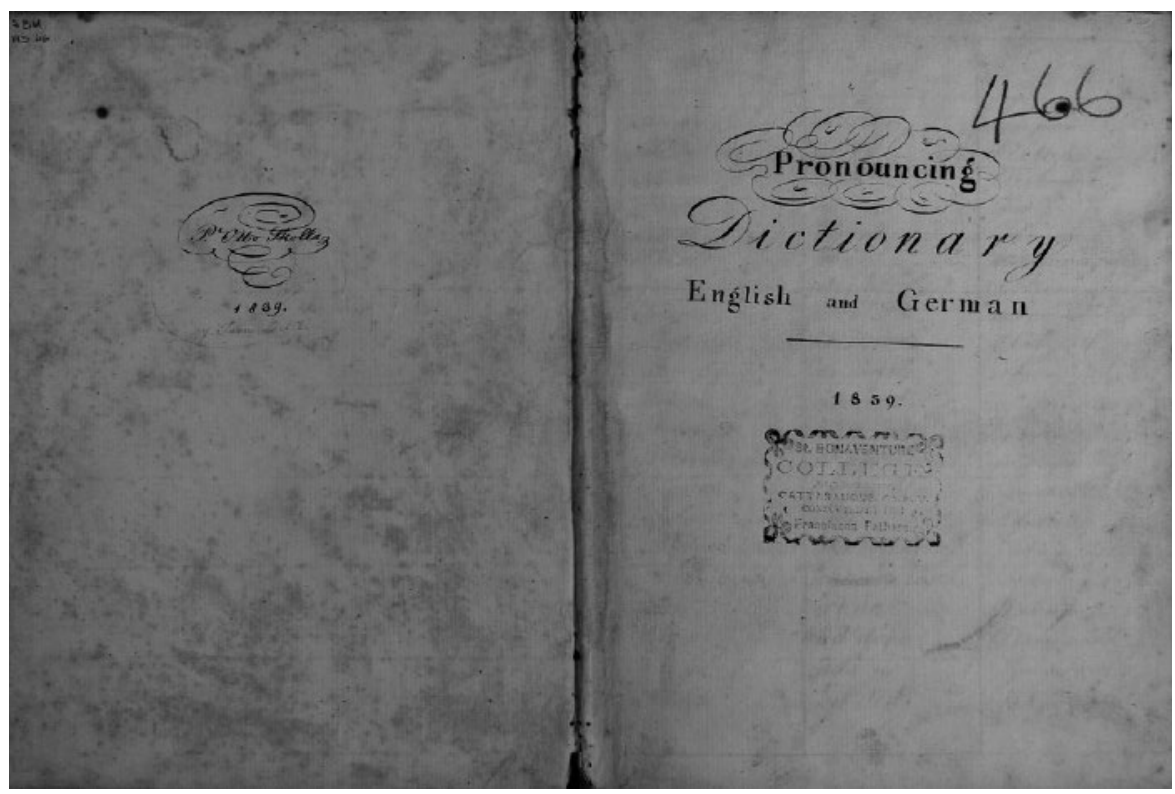

Slika 3: Naslovnica slovarja PD-EG (1839)

Struktura hitrega dostopanja uporabniku slovarja omogoča hitrejše dostopanje do makro- in mikrostrukturnih podatkov (prim. Engelberg, Lemnitzer 2009: 270). ${ }^{29} \mathrm{Za}$ dostopanje do makrostrukturnih podatkov v izgovarjalnem angleško-nemškem slovarju (tj. v seznam iztočnic) služi sprotni naslov stolpca, ki ponazarja prvo in zadnjo iztočnico na posamezni strani (npr. dia, ki je naveden nad prvo iztočnico prvega stolpca, ponazarja to prvo iztočnico, tj. Diamond; diss, ki je sicer naveden v drugem stolpcu nad izgovarjalnim razdelkom, ponazarja zadnjo iztočnico na strani, tj. Dismissal). V funkciji sprotnega naslova stolpca so tudi posamezne črke abecede s pripadajočimi iztočnicami. Te uporabnika $\mathrm{v}$ strogo abecedni razporeditvi iztočnic usmerjajo do iskane iztočnice (npr. črka $S$ uporabnika usmerja na iztočnico, ki se začne s to črko). Navedeno kaže, da je Škola imel določeno védenje o pripravi slovarja, želel pa je omogočiti tudi čim hitrejši dostop do iztočnic, kar kaže na usmerjenost $\mathrm{k}$ uporabniku. $\mathrm{V}$ glavnem seznamu slovarja in tudi v dodatku so vse iztočnice pisane z veliko začetnico, npr. Diamond, Diaphragma, Diarrhoea, Dictionary itd. Na ta način so iztočnice tudi grafično takoj prepoznavne. Podoben način zapisa iztočnic, in sicer dosledno $\mathrm{z}$ veliko začetnico, je uporabil tudi Baraga $\mathrm{v}$ svojem tiskanem slovarju A Dictionary of the Otchipwe Language (1853). Tak

${ }^{29}$ Eden od elementov strukture hitrega dostopanja je $\mathrm{v}$ tiskanih slovarji sprotni naslov stolpca (prim. Engelberg, Lemnitzer 2009: 267). 
pristop je značilen tudi za nekatere angleške slovarje tistega časa (npr. Worcesterjev slovar Comprehensive Pronouncing and Explanatory Dictionary of the English Language iz leta 1831). ${ }^{30} \mathrm{Na}$ zgornjem primeru navedenih iztočnic lahko vidimo, da je razporeditev iztočnic strogo abecedna. V primeru strogo abecedne ureditve zato dostop do besedja ni oviran ali delno prekinjen zaradi oblikoslovnih, pomenskih, izgovornih ali etimoloških vzorcev razporeditve (Müller 2002: 22). Pri strogo abecedni razporeditvi pa je dostop oviran oz. prekinjen takrat, ko razporeditev iztočnic ni dosledna. V Školovem slovarju strogo abecedna razporeditev v posameznih primerih ni povsem dosledna, kar privede do navedene prekinitve. Tako je npr. angleška iztočnica Abuse navedena pred iztočnico Abridgement in ta pred iztočnico Abreast. Iztočnica Joy je navedena pred iztočnico Joining. Iztočnica Beauty pa je navedena pred iztočnico Beautiful..$^{31}$

Iztočnice so samostalniške besede (Meeting, Merchant, Orphanage, Avarice idr.), glagoli (Go, Hide, Listen idr.), sedanjik pom. gl. biti (Are), pridevniške besede (Miscellaneous, Palpable, Pious), zaimki (She, They), prislovi (Soon, Then, Therefore), vezniki (So), predlogi (Since, Ere, T', [to]), apostrofirane oblike (T', Can't, Don't, E'er, He'd, He'll, I'd, I'll, I'm, Ne'er), ${ }^{32}$ medmeti (Aha, Alas). Kot samostojna iztočnica je vključen še deležnik (Been).

Kot iztočnice so obravnavane še nepravilne množinske oblike samostalnika (Mice, Feet, Teeth), ki imajo tudi edninsko obliko, navedeno kot iztočnico (tj. Mouse, Foot in Tooth), glagola (Shook, Stood) in pridevnik (Better). ${ }^{33}$

Slovar je glede na pomen vključenih leksemov splošen, saj vsebuje splošno izrazje v času in prostoru, tj. v diahroni zgodovinski razsežnosti 19. stol. (Steamer, Torch, Sword, Roquelaure, Sceptre, Schooner, Sennight, Server). ${ }^{34}$ Avtor slovarja nikjer ne pojasni izbora iztočnic in tudi ne kriterijev, po katerih so bile iztočnice vključene v slovar. Izrazov z verskega, tj. s krščanskega področja je $\mathrm{v}$ slovarju relativno malo, čeprav bi morda pričakovali nasprotno, saj je bil avtor duhovnik in misijonar in je tovrstno terminologijo potreboval za uspešno sporazumevanje in delovanje. Od skupno 2162 iztočnic je tako samo približno 90 (4 \%) terminov oz. izrazov, ki jih lahko prištevamo k izrazju z

${ }^{30}$ Po navedbah Osseltona (1990: 1947) se je tak zapis iztočnic v angleškem slovaropisju uveljavil v 18. stol. Poznan je tudi v nemškem slovaropisju.

${ }^{31}$ Tudi v angleških zgodovinskih slovarjih lahko zasledimo odstopanje od strogo abecedne ureditve v primerih, ko gre za izpeljanke (npr. Epidemy pred Epidemical) (prim. Osselton 1990: 1944).

${ }^{32}$ Apostrofirane oblike imajo v slovarju samostojno iztočnično-leksemsko obravnavo. Takšne oblike so uvrščene strogo abecedno (npr. I'll je uvrščen pred I'm). Nekatere apostrofirane oblike so uvrščene tudi v novejših slovarjih, npr. v Velikem angleško-slovenskem slovarju (2006).

${ }^{33} \mathrm{O}$ besedni vrsti tako lahko sklepamo iz oblike, v kateri je podana iztočnica (prim. opombo 41).

${ }^{34} \mathrm{~V}$ tem kontekstu je tudi navedba universum vocabule v spodnjem levem robu slovarja, na strani pred dodatkom. Navedbi universum vocabule, ki je napisana s svinčnikom, je dodana številka 2092, kar najbrž pomeni število iztočnic v glavnem seznamu iztočnic. 
navedenega področja, in tudi ti so v veliki meri splošno znani in razširjeni (npr. Altar, Apostle, Preacher, Bible, Psalm, Parishoners, Divinity, Christening, Bible, Abbey idr.). Avtor je vključil izrazje, ki ga uporabljajo katoličani (Chaplain, Rosary, Tonsure, Guardian, Abbey, Beatify), protestantje (Parson, Parsonage) in judje (Talmud). V slovarju ni metaleksikografskih komentarjev, ki bi pojasnili, v kateri Cerkvi se rabi določen izraz.

Poleg navedenega besedja so kot iztočnice vključene tudi sposojenke iz več jezikov. Imamo sposojenke iz francoščine (Appanage, Avoirdupois, Baggage, Bayonet, Beau, Billet-doux, Chaise, Chancre, Clientele, Connoisseur, Debauchee, Flambeau, Piquant, Rendez-vouz, Scrutoire). Med temi je tudi besedje, ki služi vzpostavljanju stika, tj. pozdrav, slovo (Adieu) in nagovarjanju oseb (Colleague, Madam). Naletimo tudi na sposojenke iz italijanščine (Bagnio, Bravo, Gambado, Intaglio, Seraglio) in latinščine (Cantharides, Fe-lo-dese, Ventriloquy). Kot iztočnice so v slovar vključena še osebna lastna imena, ki sicer nimajo slovarskega pomena (Alexander, Alfred, Anthony, Georg, Stephen, Thomas), in tudi imena iz grške ali rimske mitologije oz. zgodovine (Aeschylus, Aesopus, Myrmidons, Demosthenes, Cicero). Poleg osebnih lastnih imen so iztočnice tudi stvarna lastna imena (npr. zemljepisna imena Britain, Europe, Rome, France, Ithaca) ter imena prebivalcev, ljudstev, ras ipd. (Spaniard, Indian). $\mathrm{Z}$ diahronega gledišča nekatere vključene iztočnice prištevamo med arhaizme (Athirst, Aweary, Battailous, Bewray, Bursten, Chirurgeon, Dost, Foot-cloth, Morrow, Thy idr.).

Slovarske iztočnice so večinoma enobesedni leksemi. ${ }^{35}$ Iztočnice so pisane enobesedno (Bricklayer, Handkerchief, Musketbullets) ali z vezajem (Hobby-horses, Port-manteau, Arm-pits, Father-in-law).

\subsection{Mikrostruktura slovarja PD-EG (1839)}

Za novejše abecedno urejene tiskane slovarje (npr. Wahrig (2007) idr.) je v primerjavi z zgodovinskimi slovarji (npr. Hermannov Deutsches Wörterbuch $(1897))^{36}$ značilna relativno sistematična mikrostruktura, saj se rabijo predvsem kot priročniki. Sistematično pomeni, da vsebujejo le malo vrst slovarskih sestavkov in da je njihova zgradba v veliki meri standardizirana, tako da so leksikografske besedilne sestavine, kot so iztočnica, izgovorni podatki idr. v določenem redu na določenem mestu sestavka. Tudi za Školov slovar lahko ugotovimo sistematično mikrostrukturo. Poleg tega je za slovarske sestavke v slovarju $P D-E G(1839)$ značilna preprosta struktura. Takšno strukturo imajo novejši izgovarjalni slovarji še danes (prim. npr. Jonesonov English Pronouncing

${ }^{35} \mathrm{Za}$ zgodovinske slovarje so sicer značilne tudi večbesedne iztočnice (prim. Osselton 1990: 1946).

${ }^{36}$ Več o prvi izdaji slovarja Paula Hermanna v prispevku H. E. Wieganda (2000: 512). 
Dictionary (1997)) ${ }^{37}$ Posamezni slovarski sestavek sestoji iz naslednjih treh besedilnih segmentov, in sicer iz iztočnice, izgovarjalnega podatka in nemške ustreznice. Ti trije segmenti so urejeni v navedenem linearnem zaporedju. Ker imajo slovarski sestavki enako sestavo, $v$ slovarju prevladuje naslednja vrsta slovarskega sestavka, tj. sestavek tipa IZTOČNICA + IZGOVARJALNI PODATEK + USTREZNICA. V večini primerov je podana ena ustreznica $\mathrm{k}$ angleški iztočnici. ${ }^{38}$ Navedeno lahko vidimo v primeru naslednjih slovarskih sestavkov: ${ }^{39}$

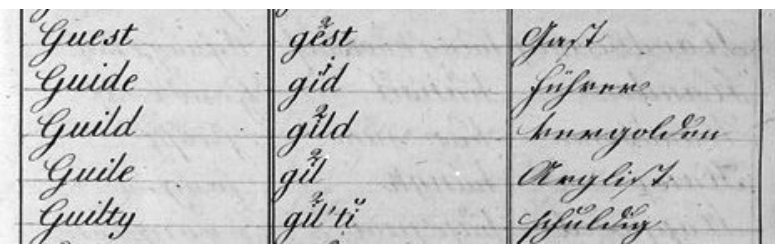

Slika 4: Slovarski sestavki v slovarju PD-EG (1839)

V primeru Guest tako slovarski sestavek sestoji iz angleške iztočnice (Guest), izgovarjalnega podatka (gêst) in nemške ustreznice (Gast). Posamezni podatki so urejeni v linearnem zaporedju, ločuje jih posamezni razdelek razpredelnice. Za ločitev posameznih podatkov je avtor rokopisnega slovarja uporabil tri različne pisave. Tako so podatki med seboj tudi grafično ločeni. Značilno za slovar je, da sta najčitljiveje zapisani iztočnica in izgovarjalni podatek, ustreznica pa je primerjalno pogosto težje berljiva. Navedeno prikazuje slovarski sestavek z angleško iztočnico Guest:

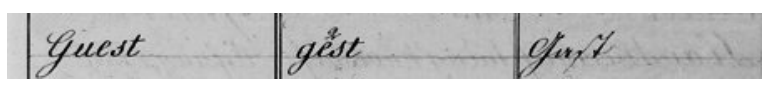

Slika 5: Slovarski sestavek k iztočnici Guest v slovarju PD-EG (1839)

V zgornjem primeru je angleška iztočnica pisana z veliko začetnico, kar je značilno za vse iztočnice tega slovarja, nemška ustreznica pa glede zapisa sledi besedni vrsti, ki je v primeru Gast samostalnik, zato zapis z veliko začetnico. ${ }^{40}$ Iz nemške ustreznice tako lahko potencialni uporabnik posredno sklepa na

${ }^{37}$ Sicer je za starejše slovarje, posebej za splošne slovarje, značilen večji delež diskurzivnosti, kot je to običajno danes (prim. Zgustov prispevek History and Dictionaries (2006)).

${ }^{38} \mathrm{~V}$ zgodovinskih slovarjih je bil velik poudarek na sinonimiji, in sicer se je vzporedno $\mathrm{k}$ tujemu leksemu dodal domač (Osselton 1990: 1947).

${ }^{39} \mathrm{~V}$ nekaterih primerih tudi sestavek tipa IZTOČNICA + IZGOVARJALNI PODATEK + POMENSKI PODATEK.

${ }^{40}$ Sredi 18. stol. se je v nemškem prostoru razmahnila razprava o nemški ortografiji, $\mathrm{v}$ ta čas pa sega tudi začetek pravopisne leksikografije (Kühn, Püschel 1990: 2091). 
besedno vrsto iztočnice, saj slovnični podatki niso vključeni v slovar. ${ }^{41}$ Podobno je v primeru angleške iztočnice Antique, kjer lahko potencialni uporabnik iz pomena nemške ustreznice sklepa, da je iztočnica pridevniška beseda.

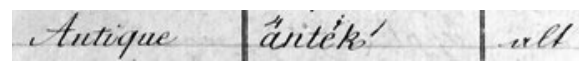

Slika 6: Slovarski sestavek k iztočnici Antique v slovarju PD-EG (1839)

Za izgovarjalne slovarje je značilno, da se grafičnim reprezentacijam leksemov pripišejo fonološke (Engelberg, Lemnitzer 2009: 46), kar je vidno v zgornjem primeru angleške iztočnice Antique. V Školovem slovarju je zapis iztočnice podan ločeno od fonetičnega zapisa, tj. v ločenem razdelku, ki sledi iztočnici in je naveden z drugo pisavo. Ponekod sta onaglašena iztočnica in tudi izgovarjalni podatek. ${ }^{42}$ Škola v slovarju za zapisovanje glasov angleških iztočnic in njihovih različkov uporablja črke latiničnega črkopisa in nekatere izvedenke iz njih ter dodatne nadpisane (ločevala), ki so črke latiničnega črkopisa in/ali cifre (prim. sliki 5 in 6). Zgornji fonetični zapis iztočnice in način zapisa pa se razlikuje od zapisa, kot ga vsebujejo angleški enojezični splošni in izgovarjalni slovarji tistega časa (npr. Sheridanov A General Dictionary of the English Language (1780), Walkerjev angleški A Critical Pronouncing Dictionary and Expositor of the English Language (1791)). ${ }^{43}$ Ker Školov slovar ne vsebuje slovarskih obbesedil, navodila $\mathrm{z}$ ustreznimi informacijami o rabi slovarja pri izgovoru posameznih iztočnic potencialnemu uporabniku niso na voljo.

\section{Sklep}

Rokopisni slovar Pronouncing Dictionary - English and German (1839), ki ga je slovenski frančiškan in misijonar ter leksikograf p. Oton Škola pripravil najverjetneje za lastno rabo, tj. da se nauči tujega jezika (angleščine) za potrebe misijonarjenja, je enosmerni dvojezični leksikografski vir, ki omogoča pasivno rabo oz. dekodiranje, tj. razumevanje govorjene in pisane angleščine 19. stol. Osnovna naloga slovarja je bila tako pomoč uporabniku pri izgovorjavi in tudi pri razumevanju angleških besed. Ta rokopisni slovar ni obsežen, saj je vanj vključenih in leksikografsko obravnavanih 2162 iztočnic. Slovar je glede na pomen vključenih leksemov splošen, saj vsebuje splošno izrazje v času in prostoru,

${ }^{41} \mathrm{~V}$ angleških zgodovinskih slovarjih so se slovnični podatki uveljavili zelo počasi. Tako je bilo o besedni vrsti možno sklepati posredno, in sicer bodisi iz pomenske razlage ali iz oblike iztočnice (npr. iz zapisa angl. iztočnice to fine lahko sklepamo, da gre za glagol). Oblikoslovnih podatkov do 18. stol. niso vključevali v slovarje (Osselton 1990: 1948).

${ }^{42}$ Iztočnica je bila najverjetneje onaglašena pozneje.

${ }^{43} \mathrm{~V}$ drugo polovico 18. stol. segajo prizadevanja za standardizacijo angleščine, tudi glede izgovorjave. K procesu standardizacije so prispevali slovarji (prim. Considine 2012: 1056). 
tj. v 19. stol. Vključene so sposojenke iz več evropskih jezikov; obseg vključenih izrazov z verskega področja je majhen. Za Školov slovar lahko ugotovimo sistematično mikrostrukturo. Za slovarske sestavke $v$ slovarju pa je značilna preprosta struktura - iztočnica, izgovarjalni podatek in nemška ustreznica. Iz zapisa nemške ustreznice (mala oz. velika začetnica) lahko običajno sklepamo na besedno vrsto angleške iztočnice (samostalnik ali drugo). Značilnost tega rokopisnega slovarja je tudi, da so posamezni podatki slovarske mikrostrukture ločeni tako strukturno kot tudi grafično, in sicer z drugačno pisavo. Fonetični zapis in način zapisa fonetičnih podatkov v slovarju se razlikuje od zapisa, kot ga vsebujejo angleški izgovarjalni slovarji tistega časa.

\section{VIRI IN LITERATURA}

Frederic BARAGA, 1853: A Dictionary of the Otchipwe Language, Explained in English. Cincinnati: Jos. A. Hemann.

John CONSIDINE, 2012: Dictionaries and the Standardization. English Historical Linguistics. An International Handbook. Vol. 1. Ur. Alexander Bergs, Laurel J. Brinton. Berlin/Boston: de Gruyter. 1050-1063.

Stefan ENGELBERG, Lothar LEMNITZER, 2009: Lexikographie und Wörterbuchbenutzung. 4. überarb. und erw. Aufl. Tübingen: Stauffenburg.

FamilySearch, 2017: New York Passenger Lists, 1820-1891, P. Otto Skolla, 1839. Https://familysearch.org/ark:/61903/1:1:QVPF-3NST. (15. april 2015). Zadnja sprememba 27. 10. 2017.

M[odest] GOLIA, 1960-1971: Skolla, Oton. Slovenski biografski leksikon. Tretja knjiga. Raab-Švikaršič. Ljubljana: Slovenska akademija znanosti in umetnosti.

--, 2017: Skolla, Oton. Slovenska biografija. Http://www.slovenska-biografija.si/oseba/ sbi575994/. Zadnja sprememba 25. 4. 2017.

Käthe GRAH, 2002: Slovenska stvarna imena v nemških besedilih = Slowenische Sachnamen in deutschen Texten. Ljubljana: Znanstveni inštitut Filozofske fakultete.

Paul HERMANN, 1897: Deutsches Wörterbuch. Halle a. S.: May Niemeyer. Https:// archive.org/details/deutscheswrter00pauluoft. Zadnja sprememba 27. 10. 2017.

Florentin HROVAT, 1889-1890: P. Oton Skola, apost. misijonar Indijanov v severni Ameriki (s 3 podobicami). Cvetje z vertov sv. Frančiška, IX (1889-1890). Gorica: [Frančiškanski samostan]. 179-187, 208-216, 277-282, 305-311, 339-345, 372-376.

Franc JAKLIČ, 1931: Misijonski škof Irenej Friderik Baraga. Celje: Družba sv. Mohorja.

Luka JERAN (ur.), (23. 12. 1858): Ogled po Slovenskim in dopisi. Zgodnja Danica: katoliški cerkveni list. Letn. 11, št. 26, 207. Https://www.dlib.si/?URN=URN:NBN:SI:DOC-XE1QBEG5. Zadnja sprememba 26. 10. 2017.

Daniel JONES, 1997: English Pronouncing Dictionary (15. izd.). Cambridge: Cambridge University Press. 
Simon KREK (ur.), 2005: Veliki angleško-slovenski slovar Oxford. Ljubljana: DZS.

Peter KÜHN, Ulrich PÜSCHEL, 1990: Die deutsche Lexikographie von den Brüdern Grimm bis Trübner. Wörterbücher / Dictionaries / Dictionnaires. Ein internationales Handbuch zur Lexikographie / An International Encyclopedia of Lexicography / Encyclopédie internationale de lexicographie (2. knj.). Ur. Franz Joseph Hausmann, Oskar Reichmann, Herbert Ernst Wiegand, Ladislav Zgusta. Berlin, New York: de Gruyter. 2078-2100.

Peter O. MÜLLER, 2002: Deutsch als Wörterbuchsprache in der mittelalterlichen und frühneuzeitlichen Lexikographie. Germanistische Lingustik 166, 21-54.

Old St. Mary's Roman Catholic Church (januar 2013): Http://detroit1701.org/St.\%20 Mary\%27s.html\#.WfIQObpFxPZ. Zadnja sprememba 26. 10. 2017.

Noel Edward OSSELTON, 1990: English Lexicography From the Beginning Up To and Including Johnson. Wörterbücher / Dictionaries / Dictionnaires. Ein internationales Handbuch zur Lexikographie / An International Encyclopedia of Lexicography / Encyclopédie internationale de lexicographie (2. zv.). Ur. Franz Joseph Hausmann, Oskar Reichmann, Herbert Ernst Wiegand, Ladislav Zgusta. Berlin, New York: de Gruyter. 1943-1953.

Robert PERIŠIĆ (ur.), 2014: Nekrologij. Hrvatska franjevačka provincija sv. Ćirila i Metoda. Zagreb: Hrvatska franjevačka provincija sv. Ćirila i Metoda.

Adalbert REBIĆ, Drago BAJT, Marta KOCJAN-BARLE (ur.), 2007: Splošni religijski

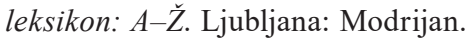

Anton Ivan REŽEK, 1906: Antoine Ivan REZEK, History of the Diocese of Sault Ste. Marie and Marquette (1. del). Houghton, Michigan. Https://archive.org/details/HistoryOfTheDioceseOfSaultSteMarieV1. Zadnja sprememba 26. 10. 2017.

James E. SEELYE, 2010: „Come into the habits of civilized life«: nineteenth century Catholic and Protestant missionaries in Upper Michigan (Doktorska disertacija). Http:// utdr.utoledo.edu/theses-dissertations/970. Zadnja sprememba 15. 9. 2017.

Thomas SHERIDAN, 1780: A General Dictionary of the English Language. London: R \& J. Dodsley, C. Dilly, J. Wilkie. Https://archive.org/stream/generaldictionar00sher\#page/ n5/mode/2up. Zadnja sprememba 27. 10. 2017.

Otto SKOLLA, 1839: Pronouncing Dictionary - English and German (Rokopis 66). Http://archives.sbu.edu/MS_Website/MuseWebsite2/sbu-post-1600-ms-66.html. Zadnja sprememba 15. 9. 2017.

St. Bonaventure University, 2017: The Lord's prayer with an invocation to the Virgin (Rokopis 65). Http://archives.sbu.edu/MS_Website/MuseWebsite2/sbu-post-1600-ms-65. html. Zadnja sprememba 26. 10. 2017.

Bo SVENSÉN, 2009: A Handbook of Lexicography. The Theory and Practice of Dictionary-Making. New York: Cambridge University Press.

Renate WAHRIG-BURFEIND (izd.), 2007: WAHRIG Wörterbuch der deutschen Sprache. München: Deutscher Taschenbuch Verlag.

John WALKER, 1791: A Critical Pronouncing Dictionary and Expositor of the English Language. London: G. G. J., J. Robinson in T. Cadell. https://archive.org/details/acriticalpronou00conggoog. Zadnja sprememba 26. 10. 2017. 
Regis M. WALLING, 1990: Biographical Introduction. The Diary of Bishop Frederic Baraga: First Bishop of Marquette, Michigan. Detroit: Wayne State University Press.

Herbert Ernst WIEGAND, 2000: Zur Geschichte des deutschen Wörterbuchs von Hermann Paul. Kleine Schriften. Eine Auswahl aus den Jahren 1970 bis 1999 in zwei Bänden. Bd. 1. Ur. Matthias Kammerer, Werner Wolski. Berlin, New York: de Gruyter. [512]-527.

Joseph Emerson, WORCESTER, 1831: Comprehensive Pronouncing and Explanatory Dictionary of the English Language with Pronouncing Vocabularies of Classical and Scripture Proper Names. Burlington: Chauncey Goodrich. Https://books.google.ad/ books?id=i_ASAAAAIAAJ\&printsec $=$ frontcover\&hl=ca\&source=gbs_ge_summary $\mathrm{r} \& \mathrm{cad}=0 \# \mathrm{v}=$ onepage \&q\&f=false. Zadnja sprememba 27. 10. 2017.

J[ohn] L. ZAPLOTNIK, 1916: Rev. Oton Skola, O. F. M. Ave Maria Koledar. New York: Uprava »Ave Maria«. [71]-102.

--, 1987: Rev. Oton Skola, O. F. M. Ave Maria. Lemont: Slovenian Franciscan Fathers of the Custody of the Holy Cross. maj 128-133, jun. 157-160, avg. 211-216, sept. 241-244, nov. 301-303, dec. 325-326.

Ladislav ZGUSTA, 2006: History and Dictionaries. Lexicography Then and Now. Selected Essays. Ur. Fredric F. M. Dolezal, Thomas B. I. Creamer. Tübingen: Niemeyer. (Lexicographica. Series Maior, 129). 1-86.

\section{FR. OTTO SKOLLA AND HIS MANUSCRIPT DICTIONARY PRONOUNCING DICTIONARY - ENGLISH AND GERMAN (1839)}

The manuscript dictionary Pronouncing Dictionary - English and German (1839) was compiled by the Slovenian Franciscan missionary, lexicographer and painter, Fr. Otto Skolla, most probably for his own use, i.e. to learn a foreign language (English) for missionary purposes. It is a monodirectional bilingual dictionary and was intended for passive use and decoding respectively, i. e. for the reception of spoken and written English of the $19^{\text {th }}$ century. The primary purpose of the dictionary was to help its user properly pronounce and understand English words. This dictionary is small in scope, containing a total of 2162 lemmas with pronunciation data and German equivalents. Skolla's dictionary is a general dictionary as it contains the general language of that time. The dictionary also includes loanwords from several other European languages. The number of religious terms is low. Dictionary articles have a simple structure. A single dictionary article consists of three textual segments: lemma, pronunciation data, and a German equivalent. In some cases, certain grammatical data (e.g. part of speech) of a particular English lemma can be determined by the way the German equivalent is written (capital letters or small letters). The individual data in the microstructure of this dictionary are separated structurally and graphically as they are placed in separate sections and written in a different handwriting style. The phonetic notation and the way the phonetic data are presented differ from that used in other dictionaries of that time. 